\title{
Phenolic Compounds and Antifungal Activity of Hedera helix L. (Ivy) Flowers and Fruits
}

\author{
Marcel PÂRVU ${ }^{1 *}$, Laurian VLASE², Alina E. PÂRVU³, Oana ROSCA-CASIAN ${ }^{4}$, \\ Ana-Maria GHELDIU², Ovidiu PÂRVU ${ }^{5}$ \\ I"Babes-Bolyai"University, Faculty of Biology and Geology, Department of Biology, 42 Republicii Street, 400015 Cluj-Napoca, \\ Romania; marcel.parvu@ubbcluj.ro (*orrespondingauthor) \\ 2"Iuliu Hatieganu"University of Medicine and Pharmacy, Faculty of Pharmacy, Department of Pharmaceutical Technology and Biopharmaceutics, \\ 12 IonCreangaStreet, 400010Cluj-Napoca, Romania; laurian.vlase@yahoo.com \\ 3"Iuliu Hatieganu"University of Medicine and Pharmacy, Faculty of Medicine, Department of Pathophysiology, 3 Victor Babes Street, \\ 400012Cluj-Napoca,Romania;parvualinaelena@yahoo.com \\ 4"Babes-Bolyai"University, "A. Borza"Botanical Garden, 42 Republicii Street, 400015 Cluj-Napoca, Romania; casioana@yahoo.com \\ s"Babes-Bolyai"University, Faculty of Mathematics and Computer Science, 1 Kogălniceanu Street, 400084 Cluj-Napoca, Romania; ovidiu.parvu@gmail.com
}

\begin{abstract}
Identification and quantitative analysis of the phenolic compounds from Hedera helix L. (ivy) flower and fruit ethanol extracts by LC/MS, in vitro germination and growth inhibition effects on Aspergillus niger, Botrytis cinerea, Fusarium oxysporum f.sp. tulipae, Penicillium gladioli and Sclerotinia sclerotiorum were performed. In the non-hydrolyzed samples of flower and fruit extracts were determined, in different amounts, five polyphenols (p-coumaric acid, ferulic acid, rutoside, quercetol and kaempferol) while quercitrin was identified only in the ivy flower extract. The hydrolyzed samples of the same ivy extracts indicated four phenolic compounds (p-coumaric acid, ferulic acid, quercetol and kaempferol), in different concentrations, whereas sinapic acid was only detected in the ivy fruit extract. The antifungal activity of the fresh flower extract was stronger than that of the fresh fruit extract and was compared to that of an antimycotic drug.
\end{abstract}

Keywords: agar-dilution assay, concentration, ethanol extracts, LC/MS, phytopathogenic fungi, quercetol, rutoside

\section{Introduction}

Hedera helix L. (ivy) is an evergreen woody liana of Araliaceae family which presents alternate and evergreen leaves, with accentuated polymorphism. The ivy flowers produced from summer until late autumn are small, greenishyellow and the fruits are small black berries, ripening in winter. Common ivy naturally grows in the Western, Central and Southern Europe, but has also been introduced to North America and Asia (Gruenwald et al., 2000). H. helix is a popular ornamental plant in many countries and it is used as a medicinal plant (Ferrara et al., 2013; Gruenwald et al., 2000; Lutsenko et al., 2010).

Regarding the chemical composition and biological activity of $H$. helix leaves literature mentions different information (Ferrara et al., 2013; Lutsenko et al., 2010; Mandade et al., 2010), but there are little data about fruits (Bedir et al., 2000; Lutsenko et al., 2010) and especially ivy flowers.
The $H$. helix leaves contain saponins (Lutsenko et al., 2010; Sieben et al., 2009; Song et al., 2014), flavonoids (Trute and Nahrstedt, 1997), phenolic acids (Wichtl, 2004), emetine alkaloid (Mahran et al., 1975), aminoacids (Ferrara et al., 2013), sterols (Wichtl, 2004), proteins (Ferrara et al., 2013), vitamins (Wichtl, 2004), polyacetylenes (Gafner et al., 1989; Wichtl, 2004) etc. Other studies revealed active constituents from the $H$. helix fruits (Lutsenko et al., 2010) like triterpene saponins (Bedir et al., 2000), fatty acids (Grosbois, 1971, 1976), polyacetylenes (Christensen et al., 1991) and $\beta$-lectins (Gleeson and Jermyn, 1979).

The main objectives of this study were to evaluate the fungicide potential of the ivy flower and fruit extracts against five economically important plant pathogens, selected from different taxonomic groups, and to determine polyphenols from these extracts known as antifungal compounds (Arif $e t$ al., 2011; Del Río et al., 2000; Lattanzio et al., 2006), since different studies present antibacterial activity of the $H$. helix 
54

leaf extract against Erwinia amylovora on apple (Baysal et al., 2002; Baysal and Zeller, 2004) and phytopathogenic fungi like Phytophthora infestans, Pseudoperonospora cubensis (Röhner et al., 2004), Alternaria solani (Yanar et al., 2011) etc.

\section{Materials and methods}

\section{Plantmaterial}

Ivy (Hedera helix L.) was collected from the A. Borza Botanical Garden in Cluj-Napoca (46.45'36 $6^{\prime \prime} \mathrm{N}$ and $\left.23^{\circ} 35^{\prime} 13^{\prime \prime} \mathrm{E}\right)$ and was identified by Dr. M. Parvu, Babes-Bolyai University of ClujNapoca. A voucher specimen (CL 664210) was deposited at the Herbarium of Babes-Bolyai University, Cluj-Napoca, Romania.

\section{Plant extract preparation}

Fragments $(0.5-1 \mathrm{~cm})$ from flowers and fruits, respectively, were extracted with 70\% ethanol in the Mycology Laboratory of Babes-Bolyai University, Cluj-Napoca, Romania, by cold repercolation method (Mishra and Verma, 2009; Sundaram and Gurumoorthi, 2012) at room temperature, for 3 days (Sundaram and Gurumoorthi, 2012) to obtain the two $H$. helix extracts. The ivy flowers were harvested in 23.09.2011 and the fruits in 29.12.2011. The content of plant extracts (w/v; g/ml) was $1 / 1.1$ for flower extract and $1 / 1$ for fruit extract.

\section{Preparation offungal colonies}

Aspergillus niger Tiegh. isolated from Allium cepa L. bulbs, Botrytis cinerea Pers. isolated from 'Kordes Perfecta' rose flowers, Fusarium oxysporum f. sp. tulipae W.C. Snyder and H.N. Hansen isolated from Tulipa gesneriana L. flowers, Penicillium gladioli Machacek isolated from Gladiolus x bybridus C. Morr. corms, Sclerotinia sclerotiorum (Lib.) de Bary isolated from Daucus carota L. roots, were included in this study. All the fungal species were identified in the Mycology Laboratory, Babes-Bolyai University, Cluj-Napoca, Romania, by Dr. M. Parvu. Colonies were obtained in Petri dishes on Czapek-agar medium (BD Difco, Budapest, Hungary), by inoculation in the central point and incubation at 22 ${ }^{\circ} \mathrm{C}$ for 5 days.

Identification and quantitative determinations of the polyphenols A high-performance liquid chromatography method coupled with mass spectrometry (LC/MS) was used to analyze the polyphenolic compounds in the $H$. helix plant extracts. The method used was a previously published HPLC method with minor changes (Compaore et al., 2012; Mocan et al., 2014; Vlase et al., 2013). The method is suitable for qualitative (18 compounds) and quantitative (14 compounds) analyses. In this study, 18 standards of the polyphenolic compounds were used, namely caftaric acid, gentisic acid, caffeic acid, chlorogenic acid, paracoumaric acid, ferulic acid, sinapic acid, hyperoside, isoquercitrin, rutoside, myricetol, fisetin, quercitrin, quercetol, patuletine, luteolin, kaempferol, and apigenin (Mocan et al., 2014; Vlase et al., 2013).

The experiments were performed using an Agilent 1100 HPLC Series system equipped with a degasser, binary gradient pump, column thermostat, autosampler and UV detector. The HPLC system was coupled with an Agilent 1100 mass spectrometer (LC/MSD ion trap VL). For the separation, a reverse-phase analytical column was employed (Zorbax SB-C18 $100 \times 3.0 \mathrm{~mm}$ i.d., $3.5 \mu \mathrm{m}$ particle); the temperature was $48^{\circ} \mathrm{C}$.
The compounds were detected in both the UV and MS mode. The MS signal was used only for qualitative analysis based on the specific mass spectra of each polyphenol (Mocan et al., 2014; Vlase et al.,2013).

Four polyphenols could not be quantified under the chromatographic conditions because of overlapping (caftaric acid with gentisic acid and caffeic acid with chlorogenic acid). However, all 4 compounds were selectively identified using MS detection (qualitative analysis) based on differences in their molecular mass and MS spectra (Vlase et al., 2013).

\section{Determination of antifungal activity}

The antifungal activity of $H$. helix flower and fruit extracts, expressed as minimum inhibitory concentration (MIC), was determined by the agar-dilution assay, and was compared to the antimycotic drug fluconazole ( $2 \mathrm{mg} \cdot \mathrm{mL}^{-1}, \mathrm{Krka}$, Novo Mesto, Slovenia) and a control (nutritive medium and $70 \%$ ethanol). The percentage of fungal growth inhibition $(P)$ at each concentration was calculated using the formula $P=(C-T) \times 100 / C$, where $C$ is the diameter of the control colony and $T$ is the diameter of the treated colony (Nidiry and Babu, 2005). MIC was considered the lowest concentration that completely inhibited the pathogen growth according to a visual evaluation (Pinto et al., 2010).

\section{Statistical analysis}

Statistical analyses were performed using the program $\mathrm{R}$ environment, version 2.14.1. The results for each group were expressed as mean \pm standard deviation. Data were evaluated by analysis of variance (ANOVA). A P value of $\leq 0.05$ was considered statistically significant. The correlation analysis was performed by the Pearson test.

\section{Results and discussions}

\section{Quantitative analysis of polyphenolic compounds}

The non-hydrolyzed sample (Fig. 1) of $H$. helix flower extract contains p-coumaric acid $\left(1.043 \mu \mathrm{g} \cdot \mathrm{mL}^{-1}\right)$, ferulic acid $\left(0.506 \mu \mathrm{g} \cdot \mathrm{mL}^{-1}\right)$, rutoside $\left(129.711 \mu \mathrm{g} \cdot \mathrm{mL}^{-1}\right)$, quercitrin $(1.300$ $\left.\mu \mathrm{g} \cdot \mathrm{mL}^{-1}\right)$, quercetol $\left(7.111 \mu \mathrm{g} \cdot \mathrm{mL}^{-1}\right)$, kaempferol $\left(7.911 \mu \mathrm{g} \cdot \mathrm{mL}^{-1}\right)$, whereas the hydrolyzed sample (Fig. 2) of the same extract revealed p-coumaric acid $\left(1.404 \mu \mathrm{g} \cdot \mathrm{mL}^{-1}\right)$, ferulic acid $(0.961$ $\left.\mu \mathrm{g} \cdot \mathrm{mL}^{-1}\right)$, quercetol $\left(37.777 \mu \mathrm{g} \cdot \mathrm{mL}^{-1}\right)$ and kaempferol (20.581 $\left.\mu \mathrm{g} \cdot \mathrm{mL}^{-1}\right)$.

The analysis of polyphenols from the non-hydrolyzed sample (Fig. 3) of the $H$. belix fruit extract revealed the presence of $\mathrm{p}$ coumaric acid $\left(0.682 \mu \mathrm{g} \cdot \mathrm{mL}^{-1}\right)$, ferulic acid $\left(3.237 \mu \mathrm{g} \cdot \mathrm{mL}^{-1}\right)$, rutoside $\left(169.643 \mu \mathrm{g} \cdot \mathrm{mL}^{-1}\right)$, quercetol $\left(2.156 \mu \mathrm{g} \cdot \mathrm{mL}^{-1}\right)$ and kaempferol $\left(1.146 \mu \mathrm{g} \cdot \mathrm{mL}^{-1}\right)$, while the hydrolyzed sample (Fig. 4) of the same extract indicated p-coumaric acid $\left(0.862 \mu \mathrm{g} \cdot \mathrm{mL}^{-1}\right)$, ferulic acid $\left(2.933 \mu \mathrm{g} \cdot \mathrm{mL}^{-1}\right)$, sinapic acid $\left(0.660 \mu \mathrm{g} \cdot \mathrm{mL}^{-1}\right)$, quercetol $\left(31.886 \mu \mathrm{g} \cdot \mathrm{mL}^{-1}\right)$ and kaempferol $\left(3.865 \mu \mathrm{g} \cdot \mathrm{mL}^{-1}\right)$.

\section{Antifungal activity}

The results of the antifungal assays of $H$. belix extracts are presented in Table 1. H. helix flower extract MIC was $12 \%$ for $A$. niger, $8 \%$ for $B$. cinerea and $S$. sclerotiorum, $10 \%$ for $F$.oxysporum f. sp. tulipae and P.gladioli.

$H$. helix fruit extract MIC was $14 \%$ for $A$. niger, $10 \%$ for $B$. cinerea and $S$. sclerotiorum, $12 \%$ for F.oxysporum f. sp. tulipae and for P.gladioli. 


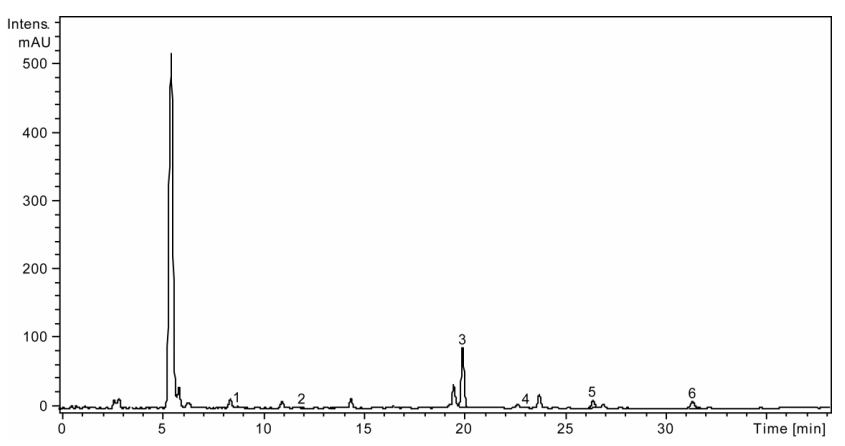

Fig. 1. Chromatogram of polyphenols from the non-hydrolyzed sample of Hedera helix flower extract. The peaks are marked: "1" pcoumaric acid; "2" Ferulic acid; “3” Rutoside; “4” Quercitrin; "5” Quercetol; "6" Kaempferol

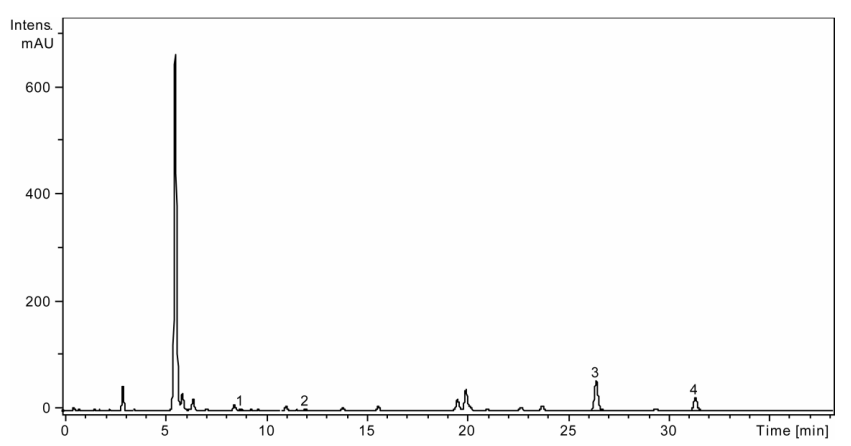

Fig. 2. Chromatogram of polyphenols from the hydrolyzed sample of Hedera helix flower extract. The peaks are marked: "1" pcoumaric acid; "2” Ferulic acid; “3” Quercetol; “4” Kaempferol

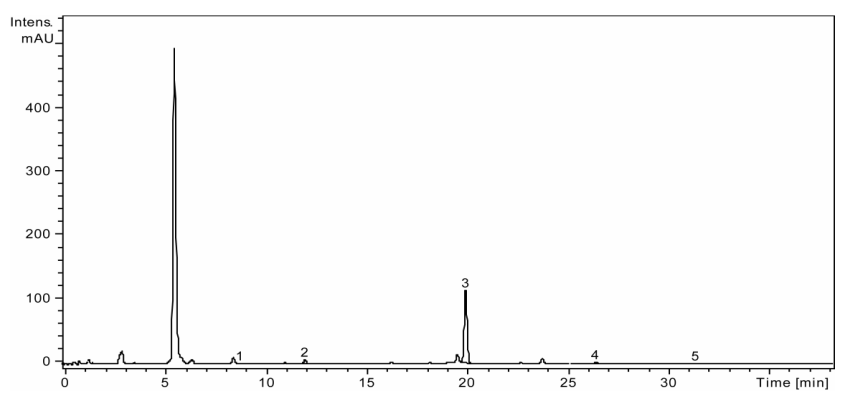

Fig. 3. Chromatogram of polyphenols from the non-hydrolyzed sample of Hedera helix fruits extract. The peaks are marked: "1" pcoumaric acid; "2" Ferulic acid; "3" Rutoside; "4" Quercetol; "5" Kaempferol

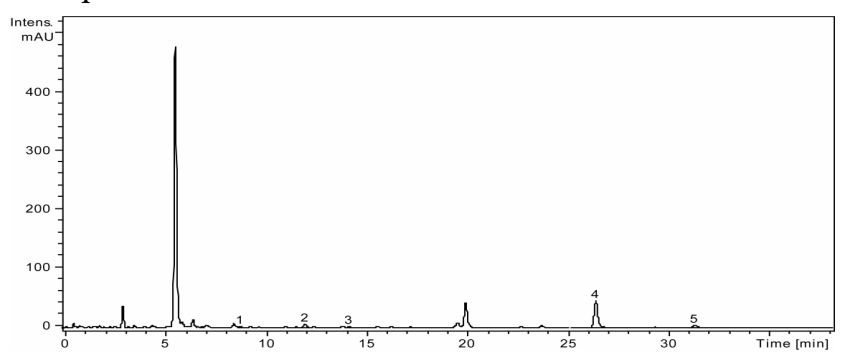

Fig. 4. Chromatogram of polyphenols from the hydrolyzed sample of Hedera helix fruits extract. The peaks are marked: "1" p-coumaric acid; "2” Ferulic acid; “3” Sinapic acid; “4” Quercetol; “5” Kaempferol
Fluconazole MIC was $30 \%$ for $A$. niger and $P$.gladioli, $12 \%$ for $B$. cinerea, $10 \%$ for F. oxysporum f. sp. tulipae and $8 \%$ for $S$. sclerotiorum (Table 1).

The inhibitory effect of $H$. helix flower extract was stronger than that of the fruit extract for all concentrations and for all tested fungi $(\mathrm{P}<0.001)$.

Since generally the active antifungal compounds of most plant extracts are phenolic compounds (El-Khateeb et al., 2013), the analysis of polyhenols from flowers and fruits (Figs. 1-4) is necessary for studying the antifungal effects of ivy extracts.

The identification and quantitative determinations of the polyphenols from ivy flowers and fruits are in agreement with other authors who mention that there are differences regarding these compounds in relation to the plant species (El-Khateeb et al., 2013; Mocan et al., 2014; Wojdyło et al., 2007), plant organ (Singh et al., 2011; Wojdyło et al., 2007) and each analyzed polyphenol (Ferrara et al., 2013; Mocan et al., 2014; Vlase et al., 2013; Wojdyło et al., 2007).

The ivy extracts obtained from leaves (Ferrara et al., 2013), flowers (Fig. 1) and fruits (Fig. 2) contain polyphenols in different concentrations. So, $H$. helix leaves contain rutin, quercetin, kaempferol and apigenin in different quantities. In the nonhydrolyzed samples of the ivy flower and fruit extracts were determined five polyphenols (p-coumaric acid, ferulic acid, rutoside, quercetol and kaempferol) in different amounts, in relation to analysed phenolic compound, while quercitrin was determined only in the ivy flower extract. The hydrolyzed samples of the ivy extracts indicated four phenolic compounds (p-coumaric acid, ferulic acid, quercetol and kaempferol) in different concentrations, whereas sinapic acid was identified only in the ivy fruit extract. In higher quantities, the phenolic compounds pcoumaric acid, quercetol and kaempferol were determined in the non-hydrolyzed and hydrolyzed flower extracts (Figs. 1 and 2), while polyphenols ferulic acid and rutoside in the ivy fruit extract (Figs. 3 and 4). Rutoside was the dominant phenolic compound in both non-hydrolyzed ivy extracts and quercetol was in hydrolyzed samples of the same extracts.

Some polyphenols identified in $H$. helix flowers and fruits extracts as p-coumaric acid, kaempferol, rutoside, showed important antibacterial and antifungal effects (Del Río et al., 2000; Singh et al., 2011; Stojković et al., 2013). The phenolic compound kaempferol obtained from Cassia renigera Wall. presented significant antifungal effects against Aspergillus flavus, A. niger, Fusarium moniliforme and Rhizoctonia bataticola phytopathogenic fungi (Singh et al., 2011). Moreover, all phenolic compounds identified in Olea europaea and Citrus spp. acted as antifungal agents and were capable of inhibiting the growth of phytopathogenic fungi (Del Río et al., 2000). The antimicrobial activity of phenolic extracts obtained from wild edible species against postharvest fungal pathogens had been little explored (Gatto et al., 2011). Moreover, the phenolic compounds verbascoside and isoverbascoside isolated from Orobanche crenata proved to be effective for biological control of important phytopathogenic fungi of fresh fruit and vegetables (Gatto et al., 2013). The antifungal activity of polyphenols verbascoside and isoverbascoside depends on pathogenic species. So, verbascoside showed significant activity against Penicillium italicum and little activity against Botrytis cinerea, Monilinia fructicola and Penicillium digitatum, while isoverbascoside 
56

Table 1. Antifungal activity of Hedera helix flower and fruit extracts on in vitro germination and growth of some phytopathogenic fungi

\begin{tabular}{|c|c|c|c|c|c|c|c|c|c|}
\hline $\begin{array}{l}\text { Phytopa- } \\
\text { thogenic fungi }\end{array}$ & $\begin{array}{c}\text { Flower } \\
\text { extract } \\
\text { conc. } \\
(\%)\end{array}$ & $\begin{array}{l}\text { Colony }^{\mathrm{a}} \\
\text { diameter } \\
(\mathrm{mm})\end{array}$ & $\mathrm{P}^{\mathrm{a}}$ & $\begin{array}{l}\text { Fruit } \\
\text { extract } \\
\text { conc. } \\
(\%)\end{array}$ & $\begin{array}{l}\text { Colony }^{\mathrm{b}} \\
\text { diameter } \\
(\mathrm{mm})\end{array}$ & $\mathrm{P}^{\mathrm{b}}$ & $\begin{array}{l}\text { Flucona- } \\
\text { zole } \\
\text { conc. } \\
(\%)\end{array}$ & $\begin{array}{l}\text { Colony }^{c} \\
\text { diameter } \\
\quad(\mathrm{mm})\end{array}$ & $\mathrm{P}^{\mathrm{c}}$ \\
\hline \multirow[t]{7}{*}{$\begin{array}{l}\text { Aspergillus } \\
\text { niger }\end{array}$} & $\mathrm{C}^{\mathrm{e}}$ & 22 & 0 & $\mathrm{C}^{\mathrm{e}}$ & 22 & 0 & $\mathrm{C}^{\mathrm{e}}$ & 22 & 0 \\
\hline & 2 & 19 & $13.63 \pm 0.81$ & 4 & 18 & $18.18 \pm 0.81$ & 10 & 12 & $45.45 \pm 0.81$ \\
\hline & 4 & 14 & $36.36 \pm 0.81$ & 6 & 13.5 & $38.63 \pm 0.57$ & 20 & 7 & $68.18 \pm 0.81$ \\
\hline & 6 & 10.25 & $53.40 \pm 0.50$ & 8 & 10 & $54.54 \pm 0.81$ & 25 & 2.75 & $87.50 \pm 0.5$ \\
\hline & 8 & 6.5 & $70.45 \pm 0.57$ & 10 & 5 & $77.27 \pm 0.81$ & 30 & 0 & 100 \\
\hline & 10 & 3 & $86.36 \pm 0.81$ & 12 & 2.5 & $88.63 \pm 0.57$ & & & \\
\hline & 12 & 0 & 100 & 14 & 0 & 100 & & & \\
\hline \multirow[t]{6}{*}{ Botrytis cinerea } & $\mathrm{C}^{\mathrm{e}}$ & 65 & 0 & $\mathrm{C}^{\mathrm{e}}$ & 65 & 0 & $\mathrm{C}^{\mathrm{e}}$ & 65 & 0 \\
\hline & 2 & 55 & $15.38 \pm 0.81$ & 2 & 60 & $7.69 \pm 0.81$ & 2 & 40.5 & $37.69 \pm 0.57$ \\
\hline & 4 & 31 & $52.30 \pm 0.81$ & 4 & 40.5 & $37.69 \pm 0.57$ & 6 & 20.25 & $68.84 \pm 0.5$ \\
\hline & 6 & 3.75 & $94.23 \pm 0.50$ & 6 & 22 & $66.15 \pm 0.81$ & 10 & 3 & $95.38 \pm 0.81$ \\
\hline & 8 & 0 & 100 & 8 & 5 & $92.30 \pm 0.81$ & 12 & 0 & 100 \\
\hline & & & & 10 & 0 & 100 & & & \\
\hline \multirow{6}{*}{$\begin{array}{l}\text { Fusarium } \\
\text { oxysporum f.sp. } \\
\text { tulipae }\end{array}$} & $\mathrm{C}^{\mathrm{e}}$ & 34 & 0 & $\mathrm{C}^{\mathrm{e}}$ & 34 & 0 & $\mathrm{C}^{e}$ & 34 & 0 \\
\hline & 2 & 28 & $17.64 \pm 0.81$ & 4 & 32 & $5.88 \pm 0.81$ & 2 & 20 & $41.17 \pm 0.81$ \\
\hline & 4 & 19 & $44.11 \pm 0.81$ & 6 & 21 & $38.23 \pm 0.81$ & 6 & 8 & $76.47 \pm 0.81$ \\
\hline & 6 & 10 & $70.58 \pm 0.81$ & 8 & 10.75 & $68.38 \pm 0.50$ & 8 & 2 & $94.11 \pm 0.81$ \\
\hline & 8 & 2.25 & $93.38 \pm 0.50$ & 10 & 2.5 & $92.64 \pm 0.57$ & 10 & 0 & 100 \\
\hline & 10 & 0 & 100 & 12 & 0 & 100 & & & \\
\hline \multirow[t]{6}{*}{$\begin{array}{l}\text { Penicillium } \\
\text { gladioli }\end{array}$} & $\mathrm{C}^{\mathrm{e}}$ & 15 & 0 & $\mathrm{C}^{\mathrm{e}}$ & 15 & 0 & $\mathrm{C}^{\mathrm{e}}$ & 15 & 0 \\
\hline & 2 & 13 & $13.33 \pm 0.81$ & 4 & 12 & $20 \pm 0.81$ & 10 & 11 & $26.66 \pm 0.81$ \\
\hline & 4 & 8 & $46.66 \pm 0.81$ & 6 & 8 & $46.66 \pm 0.81$ & 16 & 10 & $33.33 \pm 0.81$ \\
\hline & 6 & 5.50 & $63.33 \pm 0.57$ & 8 & 5 & $66.66 \pm 0.81$ & 20 & 7.5 & $50.0 \pm 0.57$ \\
\hline & 8 & 2 & $86.66 \pm 0.81$ & 10 & 2.25 & $85.0 \pm 0.50$ & 25 & 3.75 & $75.0 \pm 0.50$ \\
\hline & 10 & 0 & 100 & 12 & 0 & 100 & 30 & 0 & 100 \\
\hline \multirow[t]{6}{*}{$\begin{array}{l}\text { Sclerotinia } \\
\text { sclerotiorum }\end{array}$} & $\mathrm{C}^{\mathrm{e}}$ & 64 & 0 & $\mathrm{C}^{\mathrm{e}}$ & 64 & 0 & $\mathrm{C}^{\mathrm{e}}$ & 64 & 0 \\
\hline & 2 & 52 & $18.75 \pm 0.81$ & 2 & 58 & $9.37 \pm 0.81$ & 2 & 30 & $53.12 \pm 0.81$ \\
\hline & 4 & 31 & $51.56 \pm 0.81$ & 4 & 37 & $42.18 \pm 0.81$ & 4 & 14.50 & $77.34 \pm 0.57$ \\
\hline & 6 & 2.75 & $95.70 \pm 0.50$ & 6 & 13 & $79.68 \pm 0.81$ & 6 & 4.75 & $92.57 \pm 0.50$ \\
\hline & 8 & 0 & 100 & 8 & 2.25 & $96.48 \pm 0.50$ & 8 & 0 & 100 \\
\hline & & & & 10 & 0 & 100 & & & \\
\hline
\end{tabular}

Legend: ${ }^{\mathrm{a}}=$ the effect of $\mathrm{H}$. helix flower extract; ${ }^{\mathrm{b}}=$ the effect of $\mathrm{H}$. helix fruit extract; ${ }^{\mathrm{c}}=$ the effect of Fluconazole; $\mathrm{C}=\mathrm{control}(50 \%$ aq. EtOH $) ; \mathrm{P}=\mathrm{mycelial}$ growth inhibition - results are the mean \pm SD of 4 experiments. The same doses of $H$. belix flower and fruit extracts were tested against all fungal species

completely inhibited Botrytis cinerea, Penicillium digitatum, $P$. italicum and $P$. expansum and was less effective against $M$. fructicola (Gatto et al., 2013).

The mechanisms of action thought to be responsible for phenolic toxicity involve enzyme inhibition by the oxidized compounds, possibly through reaction with sulfhydryl groups or nonspecific interactions with the proteins (Arif et al., 2009; Mason and Wasserman, 1987).

The Hedera helix L. (ivy) extracts possess antifungal activities due to polyphenols p-coumaric acid, kaempferol, rutoside etc. (Del Río et al., 2000; Singh et al., 2011; Stojković et al., 2013) and the inhibitory effect of flower extract was stronger than that of the fruit extract, against all tested fungi (Table 1). The MIC of $H$. belix flower and fruit extracts depended on the pathogenic species and on the biologically active compounds content of the extracts (Al-Reza et al., 2010; El-Khateeb et al., 2013; Dissanayake, 2014). In general, there is a positive relation between the concentration of the plant extracts and the inhibition rate of mycelia growth in all tested fungi (El-Khateeb et al., 2013).

Our results (Table 1) completed the literature data which mention different antimicrobial effects of $H$. belix extracts against phytopathogenic bacteria and fungi: antibacterial activity against Erwinia amylovora (Baysal et al., 2002; Baysal and Zeller, 2004); a high degree of antifungal activity against Phytophthora infestans from tomato and Pseudoperonospora cubensis from cucumber (Röhner et al., 2004); an insignificant antifungal effect against Alternaria solani from potato (Yanar et al., 2011); an ineffective antifungal action against in vitro growth of the fungus Colletotrichum lindemuthianum from common bean (Pinto et al.,2010).

The antifungal effects of the ivy extracts recommend them as good candidates for the in vivo biological control of phytopathogenic fungi similar to other fungicide plant extracts 
known for their antifungal activity (Al-Reza et al., 2010; Dissanayake, 2014; El-Khateeb et al., 2013; Ribera and Zuñiga, 2012), limiting the abuse of chemical fungicides (Gatto et al, 2013; Lattanzio et al., 2006; Pârvu and Pârvu, 2011).

\section{Conclusions}

The quantitative and qualitative analysis of polyphenols revealed differences among these compounds in $H$. belix extracts and completed the literature regarding the chemical composition of ivy flower and fruit extracts. The present study clearly indicated that the ivy extracts obtained from flowers and fruits possess antifungal constituents and can be further explored as useful source of antimicrobial agents for in vivo control of plant pathogenic fungi.

\section{Acknowledgments}

This paper was published under the frame of European Social Found, Human Resources Development Operational Programme 2007-2013, project no. POSDRU/159/1.5/S/136893.

\section{References}

Al-Reza SM, Rahman A, Ahmed Y, Kang SC (2010). Inhibition of plant pathogens in vitro and in vivo with essential oil and organic extracts of Cestrum nocturnum L. Pestic Biochem Phys 96(2):86-92.

Arif T, Bhosale JD, Kumar N, Mandal TK, Bendre RS, Lavekar GS, Dabur R (2009). Natural products - antifungal agents derived from plants. J Asian Nat Products Res 11:621-638.

Arif T, Mandal TK, Dabur R (2011). Natural products: Antifungal agents derived from plants, pp 283-311. In: Tiwari VK (Ed). Opportunity, challenge and scope of natural products in medicinal chemistry. Research Singpost, Kerala, India.

Baysal O, Laux P, Zeller W (2002). Further studies on the induced resistance (IR) effect of plant extract from Hedera helix against fire blight (Erwinia amylovora) (Conference Paper). Acta Hort 590:273-277.

Baysal O, Zeller W (2004). Extract of Hedera helix induces resistance on apple rootstock M26 similar to Acibenzolar-Smethyl against fire blight (Erwinia amylovora). Physiol Mol Plant P 65(6):305-315.

Bedir E, Kirmizipekmez H, Sticher O, Calis I (2000). Triterpene saponins from the fruits of Hedera helix. Phytochemistry 53(8):905-909.

Christensen LP, Lam J, Thomasen T (1991). Polyacetylenes from the fruits of Hedera helix. Phytochemistry 30(12):4151-4152.

Compaore M, Lamien CE, Lamien-Meda A, Vlase L, Kiendrebeogo M, Ionescu C, Nacoulma OG (2012). Antioxidant, xanthine oxidase and lipoxygenase inhibitory activities and phenolics of Baubinia rufescens Lam. (Caesalpiniaceae). Nat Prod Res 26:1069-1074.
Del Río JA, Arcas MC, Botía JM, Báidez AG, Fuster MD, Ortuno AM (2000). Involvement of phenolic compounds in the antifungal defense mechanisms of Olea europaea L. and Citrus sp., pp 331-341. In: Pandalai SG (Ed). Recent Research Developments in Agricultural \& Food Chemistry. Research Signpost, Trivandrum.

Dissanayake MLMC (2014). Inhibitory effect of selected medicinal plant extracts on phytopathogenic fungus Fusarium oxysporum (Nectriaceae) Schlecht. Emend. Snyder and Hansen. Annu Res Rev Biol 4(1):133-142.

El-Khateeb AY, Elsherbiny EA, Tadros LK, Ali SM, Hamed HB (2013). Phytochemical analysis and antifungal activity of fruit leaves extracts on the mycelial growth of fungal plant pathogens. J Plant Pathol Microb 4(9):1-6.

Ferrara L, Naviglio D, Faralli S (2013). Identification of active principles of Hedera helix L. in aqueous extracts. The Journal of Phytochemistry. Photon 114:170-175.

Gafner F, Reynolds GW, Rodriguez E (1989). The diacetylene 11, 12-dehydrofalcarinol from Hedera helix. Phytochemistry 28(4):1256-1257.

Gatto MA, Ippolito A, Linsalata V, Cascarano NA, Nigro F, Vanadia S, Di Venere D (2011). Activity of extracts from wild edible herbs against postharvest fungal diseases of fruit and vegetables. Postharvest Biol Technol 61(1):72-82.

Gatto MA, Sanzani SM, Tardia P, Linsalata V, Pieralice M, Sergio L, Di Venere D (2013). Antifungal activity of total and fractionated phenolic extracts from two wild edible herbs. Natural Science 5(8):895-902.

Gleeson PA, Jermyn MA (1979). Alteration in the composition of $\beta$-lectins caused by chemical and enzymic attack. Austral J Plant Physiol 6(1):25-38.

Grosbois M (1971). Biosynthesis of fatty acids during the development of ivy fruit and seed (in French). Phytochemistry 10(6):1261-1273.

Grosbois M (1976). Changes in the amount of complex lipids in the seeds and in the pericarp during the development of ivy fruit Hedera helix. Physiol Plantarum 36(2):145-149.

Gruenwald J, Brendler T, Jaenicke C (2000). PDR for Herbal Medicines. Medical Economics Company, Montvale, $284 \mathrm{p}$.

Lattanzio V, Lattanzio VMT, Cardinali A (2006). Role of phenolics in the resistance mechanisms of plants against fungal pathogens and insects, pp 23-67. In: Imperato F (Ed). Phytochemistry: advances in research. Trivandrum, Kerala, India.

Lutsenko Y, Bylka W, Matlawska I, Darmohray R (2010). Hedera helix as a medicinal plant. Herba Pol 56(1):83-96.

Mahran GH, Hilal SH, El-Alfy TS (1975). The isolation and characterisation of emetine alkaloid from Hedera helix. Planta $\operatorname{Med} 27(2): 127-132$.

Mandade RJ, Choudhuri A, Mashirkar V, Sakarkar D (2010). Analgesic and anti-inflammatory activities of Hedera helix leaf extract. International Journal of Comprehensive Pharmacy $1(4): 1-3$. 
58

Mason TL, Wasserman BP (1987). Inactivation of red beet betaglucan synthase by native oxidized phenolic compounds. Phytochemistry 26:2197-2202.

Mishra R, Verma DL (2009). Antifungal activity and flavonoid composition of Wiesnerella denudata. Steph Academia Arena $1: 42-45$.

Mocan A, Vlase L, Vodnar DC, Bischin C, Hanganu D, Gheldiu AM, Oprean R, Silaghi-Dumitrescu R, Crisan G (2014). Polyphenolic content, antioxidant and antimicrobial activities of Lycium barbarum L. and Lycium chinense Mill. leaves. Molecules 19:10056-10073.

Nidiry ESJ, Babu CSB (2005). Antifungal activity of tuberose absolute and some of its constituents. Phytother Res 19:447449.

Pârvu M, Pârvu AE (2011). Antifungal plant extracts, pp 10551062. In: Méndez-Vilas A (Ed). Science against microbial pathogens: communicating current research and technological advances. Formatex Research Center, Badajoz, Spain.

Pinto JMA, Souza EA, Oliveira DF (2010). Use of plant extracts in the control of common bean anthracnose. Crop Protection 29(8):838-842.

Ribera AE, Zuñiga G (2012). Induced plant secondary metabolites for phytopatogenic fungi control: a review. J Soil Sci Plant Nutr 12(4):893-911.

Röhner E, Carabet A, Buchenauer H (2004). Effectiveness of plant extracts of Paeonia suffruticosa and Hedera belix against diseases caused by Phytophthora infestans in tomato and Pseudoperonospora cubensis in cucumber. J Plant Dis Prot $111(1): 83-95$.

Sieben A, Prenner L, Sorkalla T, Wolf A, Jakobs D, Runkel F, Häberlein H (2009). Alpha-hederin, but not hederacoside C and hederagenin from Hedera belix, affects the binding behavior, dynamics, and regulation of beta 2-adrenergic receptors. Biochemistry 48(15):3477-3482.
Singh D, Sharma SK, Rani R, Mishra S, Sharma RA (2011). Kaempferol-7-O-glucoside and their antimicrobial screening isolate from Cassia renigera Wall. Int J Pharm Clin Res 3(2):3034.

Stojković D, Petrović J, Soković M, Glamočlija J, Kukić-Marković J, Petrović S (2013). In situ antioxidant and antimicrobial activities of naturally occurring caffeic acid, p-coumaric acid and rutin, using food systems. Journal of the Science of Food and Agriculture 93(13):3205-3208.

Sundaram U, Gurumoorthi P (2012). Validation of HPTLC method for quantitative estimation of L-Dopa from Mucuna pruriens. Int Res J Pharm 3:300-304.

Trute A, Nahrstedt A (1997). Identification and quantitative analysis of phenolic compounds from the dry extract of Hedera helix. Planta Med 63(2):177-179.

Vlase L, Pârvu M, Pârvu EA, Toiu A (2013). Chemical constituents of three Allium species from Romania. Molecules 18(1):114127.

Wichtl M (2004). Herbal drugs and phytopharmaceuticals. A handbook for practice on a scientific basis. $3^{\text {rd }}$ Ed. Stuttgart, 274 p.

Wojdyło A, Oszmiański J, Czemerys R (2007). Antioxidant activity and phenolic compounds in 32 selected herbs. Food Chem 105:940-949.

Yanar Y, Gökçe A, Kadioglu I, Çam H, Whalon M (2011). In vitro antifungal evaluation of various plant extracts against early blight disease (Alternaria solani) of potato. Afr J Biotechnol 10(42):8291-8295. 